\title{
BIBLIOGRAFIA: LIVROS, ARTIGOS E RESENHAS PRODUZIDOS POR WARREN DEAN.
}

\author{
Dora Shellard Corrêa \\ Doutoranda em História Econômica na FFLCH-USP
}

\section{Livros como Editor}

ALDEN, D. and DEAN, W. (ed). Essays Concerning to Sociocconomic History of Brazil and Portuguese India. Gainsville, The University Press of Florida, 1977.

DEAN, W. (ed.). Reflections on the Brasilian CounterRevolution: Essays by Florcstan Fernandes. New York, M. E. Sharpe, 1981, pp. vii-xii.

et al. (ed.). Diplomatic Claims: Latin American Historians View the Unitcd States. New York U. Pr. of America, 1985.

\section{Artigos}

"The Planter as Entrepreneur: The Case of Sao Paulo". Hispanic American Historical Review, vol. XLVi: 2, 1966, pp. 138-152.

"Sources for the Study of Latin America Economic History: The Records of North American Private Enterprises". Austin, Institute of Latin American Studies, University of Texas at Austin, 1968.

"Latifundia and Land Policy in Nineteenth-Century Brazil". Hispanic American Historical Review, vol. 51: 4, 1971, pp. 606-625.
"Remessas de Dinheiro dos Imigrantes Italianos do Brasil, Argentina, Uruguai e E.U. da América: 1884-1914". Anais de Historia, Assis, Ano 6, 1974, pp. 231-237.

"A Industrializaçāo Durante a República Velha". In: FAUSTO, Boris. História Geral da Civilizaçāo Brasileira. Tomo III, vol. I Estrutura dc Poder c Economia (1889-1930). São Paulo, Difel, 1975, pp. 243-283.

"A Fábrica Săo Luiz de Itu: Um Estudo de Arqueologin Industrial". Anais de História, Assis, Ano 8, 1976, pp. 9-25.

"Os Latifúndios e a Política Agrária Brasileira no Século XIX". In: PELAEZ, C.M e BUESCU, Mircea (coord.). A Moderna História Económica. Rio de Janeiro, Apec, 1976, pp. 245-257.

"Ecological and Economic Relationship in Frontier History: São Paulo, Brazil". In: WOLFSKILl, George; PALMER, Stanley (ed.). Essays on Fronticrs in World History. Texas, A\&M University Press: College Station, 1981, pp.71-100.

"Deforestation in Southeastern Brazil". In: TURCKER, Richard, RICHARDS \& J. F. (ed.). Global Deforestation

- Este é um levantamento parcial da produçāo acadêmica do Prof. Warren Dean. Foi elaborado a partir de revistas especializadas e abstracts existentes nas bibliotecas da USP. 
and the Ninctcenth-Ccntury World Economy. Durham, Duke Press Policy Studies, 1983, pp 50-67.

Comments on: "Slavery in a Nonexport Economy: Nineteenih-Century Minas Gerais Revisited". Hispanic Amcrican Historical Revicw, 63:3, 1983, pp. 537-590.

"Indigenous Populations of the Sāo Paulo-Rio de Janciro Coast: Trade, Aldeamento, Slavery and Extinction". Rcvista de Hisıória, São Paulo, 117, 1984, pp. 3-26.

"Forest Conservation in Southeastern Brazil, 1900-1955". Environmental Revicw, vol. IX:1, 1985, pp.54-69.

"A Floresta como Fontc de Encrgia na Urbanização e na Industríalização de São Paulo: 1900-1950". In: Anais do I. Seminhrio Nacional dc História e Encrgia. Sāo Paulo, 19 a 23 de outubro de 1986, Sảo Paulo: Eletropaulo - Eletrificação de São Paulo S. A., Departamento de Pa1rimônio Histórico, 1987, pp. 41-55.

"The Green Wave of Coffee: Beginnings of Tropical Agricultural Research in Brazil (1885-1900)". Hispanic Amcrican Historical Revicw, 69:1, 1989, pp. 91-115.

"A Botanica c a Política Impcrial: a Introdução e a Domesticação de Plantas no Brasil". Estudos Históricos, Rio de Janeiro, vol. 4:8, 1991, pp. 216-228.

"The Rubber Development Schemes of the United States in the Brazilian Amazon, 1939-1956". In: Floresta 90. Simpósio Internacional de Estudos Ambicntais cm Flo. rcstas Tropicais Húmidas, 1, Manaus, 1990. Anais, Rio de Janeiro, 1992, pp. 262-267.

"The Tasks of Latin American Environmental History". In: STEEN, Harold K. \& TURCKER, Richard P. Changing Tropical Forests. Historical Perspectives on Today's Challenges in Central \& South America. Procedings of a conference sponsored by The Forest History Sociely and IUFRO Forest History Group. USA, Forest History Society, 1992.

"Revolução Ambiental c o Papel das ONGs". In: 2. Congresso Nacional sobre Essências Nativas - 29/3/92-3/4/92. Anais. Revista do Instituto Florcstal. Sāo Pauto: parte 1, 1992, pp.35-40.

The Industrialization of Sāo Paulo, 1880-1945. Austin, Institutc of Latin American Studies/University of Texas Press, 1969

Remittances of Italian Immigrants: from Brazil, Argentina, Uruguay and USA, 1884-1914. New York, New York University, 1974, 11 p. (Occasional Papers, n. 14).

Rio Claro: A Brazilian Plantation System, 1820-1920.
California, Stanford University Press, 1976.

Rio Claro: Um Sistema Brasileiro de Grande Lavoura 1820-1920. Tradução de Waldivia Marchiorì Pontinho, Rio de Janeiro, Paz e Terra, 1977. (Estudos Brasileiros, vol. 21).

As Multinacionais: Do Mcrcantilismo ao Capital Internacional. São Paulo, Brasiliense, 1983, 105 p. (Primeiros Vôos, 14).

Brasil and the Struggle for Rubbcr: A Study in Environmental History. Cambridge, Cambridge University Press, 1987. (Studies in Environmental History).

A Luta pela Borracha no Brasil: Um Estudo de História Ecologica. Traduçāo de Eduardo Brandĩo. São Paulo, Nobel, 1989.

With Broadax and Fircbrand: The Destruction of the Brazili. an Atlantic Forest. California, University of California Press, 1995.

With Broadax and Firebrand: The Destruction of the Brazili. an Allantic Forcst. (São Paulo) (A Companhia das Letras esıá traduzindo esse livro e planeja publicá-lo em junho de 1996]

\section{Artigos em Coletâneas}

“The Brazilian Economy. 1870-1930". BETHELL, Leslie. The Cambridge History of Latin America. vol. $V$, $c$. 1870 10 1930. Cambridge, Cambridge University Press, 1986, pp.685-724

“A Indusırializaçāo de São Paulo (1880-1945)". 1 " ed. Tradução de Oclávio Mendes Cajado, Săo Paulo, Difusão Européia do Livro, 1971. (Corpo e Alma do Brasil).

\section{Resenhas}

FURTADO, Celso. Diagnosis of the Brazilian Crisis. Berkeley, University of California Press, 1965, 168p.

Hispanic American Historical Review. vol. XLVI:4, 1966, p. 474.

HOLANDA, Sérgio Buarque de (ed.). História Cacral da Ci. vilizaçāo Brasilcira, vol. II: O Brasil Monárquico. Parte 2: Dispersão e Unidade. São Paulo, Difusão Européia do Livro, 549p. Hispanic American Historical Review, vol. XLVI1:2, 1967, p. 299.

LEVINE, Robert (ed.). Brazil: Ficld Rescarch Guidc in the 
Social Sciences. New York, Columbia University; Institute of Latin American Studies, 1966, p. 289. Hispanic American Historical Revicw, vol. XLVII: 3, 1967, p. 446.

FRANK, André Gunder. Capitalism and Underdevelopment in Latin America. Historical Studies of Chile and Brazil. New York, Monthly Review Press, 1967, 298p. Hispanic Amcrican Historical Review, vol. XLVIIt:3, 1968, p. 453.

FAusto, Boris A Revolução de 1930. São Paulo, Brasiljense, 1970, 118 p. Hispanic American Historical Review, vol. 51:2, 1971, p. 382.

WIRTH, John D. The Politics of Brazilian Development. 1930-1954. Stanford, Stanford Univcrsity Press, 1970, 278p. Amcrican Historical Review, vol. 76:3, 1971, p. 857.

CHILCOTE, Ronald H. (ed.). Protestant and Resistence in Angola and Brazil: Comparative Studics. (Publicação do African Sludies Center an Lalin American Center). Betkeley, University of California Press, 1972, 317p. Hispanic Amcrican Historical Review, vol. 53:4, 1973, p. 667.

GALEANO, Eduardo. Open Veins of Latin America: Five Centurics of the Pillage of a Continent. New York, Monthly Review Press, 1973, 313p. Hispanic Amcrican Historical Revicw, vol. 54:4, 1974, p. 691.

CORRÊA, Anna Maria Martinez. A Rcbclião de $1924 \mathrm{~cm}$ São Paulo. Sāo Paulo, Hucitec, 1976, 201p. Hispanic American Historical Review, vol. 57:4, 1977, p. 744.

MERRICK, Thomas W. e Graham. Population and Economic Development in Brazil: 1800 to the Present. Baltimore. John Hopkins University Press, 1979, 385p. American Historical Revicw. vol. 85:3, 1980, p. 743.

LEFF, Nathaniel H. Underdevelopment and Development in Brazil. Vol. 1: Economic Strucure and Change, 1822. 1947; vol. 2: Reassessing the Obstacles to Economic Development. Massachuselts, Alen and Unwin, 1982, 251 p. American Historical Review; vol. 88:3, 1983, p. 783. FOWERAKER, Joe. The Struggle for Land: A Political
Economy of the Pionner Fronticr in Brazil from 1930 to the Present Day. New York, Cambridge University Press, 1981, 260p. American Historical Review, vol. 89:4, 1984, p. 1193.

WEINSTEJN, Barbara. The Amazon Rubber Boon, 1850 1920. Stanford, Stanford University Press, 1983. The Americas, vol. 41, 1984, p. 141.

MORNER, Magnus \& SIMS, Harold. Adventures and Prolctarians; the Story of Migrants in Latin America. Pittsburgh, English University of Pittsburgh Press, Unesco, 1985. Labor History, vol. 27, 1986, p. 469.

STOLCKE, Verena. Cafcicultura: Homens, Mulheres c Capital (1850-1980). São Paulo, Brasiliense, 1986, 410p. Hispanic American Historical Review, 68:3, 1988, p. 621.

HARTMAN, Francisco Foot. Trem Fantasma. A Modernidadc na Selva. São Paulo, Cia. das Lelras, 1988, 291 p. Hispanic American Historical Revicw, 69:3, 1989, p. 607

BARMAN, Roderich J. Brazil: The Forging of a Nation, 1798-1852. Stanford, Stanford University Press, 1988, 334p. American Historical Revicw, vol. 95:5, 1990, p. 1663.

\section{Livros para Referência}

MEIHY, José Carlos Sebe Bom. A Colônia Brasilianista: História Oral de Vida Acadêmica. Sāo Paulo, Nova Stella, 1990.

FLASKSMAN, Dora Rocha (Ed.). "Warren Dean: Um brasilianista". Estudos Historicos 3(5), 1990, pp. 103. 113.

PONTES, Heloisa André \& MASSI, Fernanda Peixoto. Guia Bibliografico dos Brasilianistas - Obras e Autores no Brasil entre 1930 e 1988. São Paulo, Sumaré/Fapesp, 1992.

MElHY, José Carlos Sebe Bom. "Warren Dean: Um Brasilianista Acima de Qualquer Suspeita". Revista Brasilcira de Historia, $n^{2} 27,1994$, pp. 205-211. 